\title{
The Browning Factors and Analysis of Browning Speed in Mei Syrup during Storage
}

\author{
Wu Ming Chang*, Yang Ting Chen ${ }^{* *}$ and Chen Chin Shu*** \\ * National Pingtuug University of Science and Technology \\ 1 Hseuh Fu Rd. , Nei Pu, Pingtung, Taiwan \\ ** Searchan Enterprise CO., LTD. \\ $4 F$, No. 605 Ying-Tsai RD., Taichung, Taiwan \\ *** University of Florida
}

IFAS, 700 Experiment Station Road, Lake Alfred, FL 33850, USA

\begin{abstract}
The factors affecting the browning in sweetened mei (Japanese apricot) syrup during storage were investigated. When stored at 5,15 and $25^{\circ} \mathrm{C}$ for 6 or 12 months, the added sucrose in the syrup was inverted into fructose and glucose as the syrup browning progressed. Increases in 5 hydroxymethyl furfural (HMF), an intermediate of caramelization, were measured in the stored syrups. Experimental rate constants for kinetics of sugar changes and phenolic compound decreases during storage were determined. The browning reaction in sweetened mei syrup was characterized by a combination of oxidation of phenolic compounds and caramelization of sugars.
\end{abstract}

(Received Aug. 27, 1997)

Prunus ume is known as Japanese apricot which is called mei in Chinese and was originally grown in China. At present, China, Japan, North Korea, Southeast Asian nations and Taiwan produce Japanese apricot (K'ang, 1995) .

This fruit is claimed to be beneficial to the liver and intestines of humans, and helpful to relieve fatigue. It is recognized as one kind of healthy food in Japan. The fruit is believed to quench thirst, enhance appetite, and prevent food from perishing. About 80,000 tons of Japanese apricot are consumed annually in Japan, making it the top consumption nation in the world (CHOU \& FANG, 1993 ; FANG \& WANG, 1988).

ORIMO (1975) first reported the principle for mei syrup processing. In recent years, there is considerable interest in developing commercial mei fruit juice drinks (CHANG \& WU, 1985; FANG \& WANG, 1988; WANG FANG,1988). However, browning of the juice products is one of the major concerns which need to be addressed. KATO et al.
(1963) and KATO \& SAKURAI (1964 a; 1964b) studied the browning mechanism of high acid and high sweetness of fruit juice products; and depicted the change over relative constituents. Mei syrup belongs to the high acid and high sweetness fruit products mentioned above. The results from KATO et al. (1963) and KATO \& SAKURAI (1964 a; 1964 b) are a very valuable reference to the study of the browning of mei syrup. The objectives of this study were to identify factors affecting the browning reaction and to determine the kinetics of quality degradation in the sweetened mei syrup during storage.

\section{MATERIALS AND METHODS}

\section{Material and samples preparation}

The fruits of Japanese apricot were harvested on Apr. 3, 1995 from Shin-jin Shiang, Nantou County, which is $350 \mathrm{~m}$ above sea level and is the prime producing area of "Dah - ching" cultivar in Taiwan. After harvest, fruits were delivered 


\author{
Mature Mei fruits \\ Grading in size \\ $\downarrow$ \\ Ripening at room temperature for 4 days \\ $\downarrow$ \\ Washing \\ $\downarrow$ \\ Blanching in hot water at $95 \pm 2^{\circ} \mathrm{C}$ for 2.5 minutes \\ $\downarrow$ \\ Crushing \\ $\downarrow$ \\ Pulping and finishing with 20 and 60 meshes screen \\ Adding same of water and two folds of sugar \\ $\downarrow$ \\ Heating to $80^{\circ} \mathrm{C}$ and mixed well \\ $\downarrow$ \\ Filling \\ $\downarrow$ \\ Pasteurizing at $85^{\circ} \mathrm{C}$ for $5 \mathrm{~min}$ \\ Cooling \\ $\downarrow$ \\ Product
}

Fig. 1 Flow sheet for preparation of Mei syrup

directly to the local factory. The flow sheet developed by FANG and WANG (1988) as shown in Figure 1 was used. It should be noted that hot water blanching was used to inactivate the enzymes during preparation of the syrup and cane sugar was added to make a two-fold sweetened product. Test samples were prepared from the sweetened mei syrup. Triplicate test data were used for data analysis.

\section{Determination of juice syrup quality}

1) Color A color difference meter (100 DP, Denshoku Kogyo Co.) was used for measuring color differences. The equipment was calibrated by standard plate $(\mathrm{Y}=93.00, \mathrm{X}=91.60, \mathrm{Z}=109.8)$ in advance. The values of $L, a, b$, of samples were subsequently measured.

2) $\mathrm{pH}$ value $\mathrm{The} \mathrm{pH}$ values of samples were measured by the $\mathrm{pH}$ meter (Hanna, 8521 Digital type) according to CNS (1980) method.

3) Titratable acidity The CNS (1980) method was used to measure the titratable acidity. Accordingly, a sample of $25 \mathrm{~g}$ was put in a $250 \mathrm{~mL}$ beaker, heated to boiling, then cooled and added $100 \mathrm{~mL}$ degassed distilled water. The sample solution was titrated with $0.1 \mathrm{~N} \mathrm{NaOH}$ to $\mathrm{pH} 8.1$ and calculated as the citric acid content.

4) Organic acid The method of Wilson et al. (1982) was modified as follows: $10 \mathrm{~g}$ of samples were diluted with deionized water, shaken thoroughly and filtered with $0.45 \mu \mathrm{m}$ films, then the samples were injected into a High Performance Liquid Chromatograph (HPLC) .

Conditions of HPLC were as follows: Hitachi L-6000 type with L-4000 UV detector, D-2500 recorder, Jusco Finepak silc 18 column $(25 \mathrm{~cm} \times 4.6$ $\mathrm{mm}, 10 \mu \mathrm{m})$, the mobile phase of triethylamine was adjusted to $\mathrm{pH} 2$ by using phosphoric acid.

5) Free amino acids Sulfosalicylic acid, $3.75 \mathrm{~g}$, was added to the citrate solution at a final $\mathrm{pH}$ of 2.2 to a final volume of $100 \mathrm{~mL}$. The $\mathrm{pH}$ adjusts to 1.8 for use. The sample was added with sodium citrate buffer by a ratio of $1: 4$, suspended for protein sedimentation, and centrifuged at $13,000 \times$ $\mathrm{g}$ for $20 \mathrm{~min}$ under $4{ }^{\circ} \mathrm{C}$ cooling condition. The contents of free amino acids were determined by a free amino acid analyzer.

6 ) Sucrose, glucose and fructose $\mathrm{We}$ followed the method of Bergmeyer and Bernt (1974) to measure sucrose, glucose and fructose. Glucose is converted to glucose-6-phosphate $\left(\mathrm{G}^{-}{ }^{-}{ }^{-}\right.$ $\mathrm{P}$ ) and gluconate-6-phosphate accompanied by the reduction of $\mathrm{NADP}^{+}$to NADPH. The changes in optical density were measured at $340 \mathrm{~nm}$ by a photometer. Fructose was converted to fructose -6 phosphate $(\mathrm{F}-6-\mathrm{P})$ and to $\mathrm{G}-6-\mathrm{P}$ by hexokinase, phosphoglucose isomerase, then the same procedure was followed as mentioned above to determine the fructose. Sucrose was converted into glucose and fructose by $\beta$-fruotosidase, and the resulting hexoses measured as above.

7) Phenolic compounds and 5-hydroxymethyl furfural (HMF) We followed the methods of JOSE \& LUH (1973) and WULF \& NAGEL (1976) Samples of $10 \mathrm{~g}$ were added to $50 \mathrm{~m} \ell$ of $70 \%$ methanol and blended in a blender for $3 \mathrm{~min}$, filtered and the residue washed with $25 \mathrm{~mL}$ of the methanol solution. The filtrates were finally 
combined.

The filtrates were condensed at $40^{\circ} \mathrm{C}$ condition. The condensed samples were centrifuged at 13,000 $\times \mathrm{g}$ with Sorvall $\mathrm{RC}-5 \mathrm{~B}$ centrifuge for $30 \mathrm{~min}$, the upper solution was collected and filtered through $0.45 \mu \mathrm{m}$ cellulose acetate film. Both the contents of phenolic compounds and HMF were analyzed by HPLC with E. Merk Supperspher 100- RP-18 column and mobile phase of $5 \%$ acetic acid solution.

\section{Models for degradation kinetics}

The following general reaction rate expression for degradation kinetics was used for characterizing the experimental data as follows:

$$
-\mathrm{d}[\mathrm{D}] / \mathrm{dt}=\mathrm{k}[\mathrm{D}]^{\mathrm{m}} \quad \text { Eqn [1] }
$$

Where $[D]$ is the quantitative value of quality factor or the undesirable products of the degradation reaction. $\mathrm{K}$ is the reaction rate constant, and $\mathrm{m}$ is the order of the reaction.

The solutions for zero and first-order reaction are, respectively, as follows:

For a zero order reaction $(\mathrm{m}=0)$,

$$
[D]_{\mathrm{t}}=\mathrm{C}+\mathrm{kt} \quad \text { Eqn [2] }
$$

where $\mathrm{c}$ is an empirical constant at time 0 ;

For a first-order reaction $(m=1)$,

$$
\ln \left([\mathrm{D}] . /[\mathrm{D}]_{\mathrm{t}}\right)=\mathrm{kt} \quad \text { Eqn }[3]
$$

where $[D]$. is the value of the quality factor at time $\mathrm{O}$ and $[\mathrm{D}]_{\mathrm{t}}$ is the value after reaction time $\mathrm{t}$.

Eqn [3] can be written as:

$\log [\mathrm{D}]_{\mathrm{t}}=\log [\mathrm{D}]_{\mathrm{o}}-(\mathrm{k} / 2.303)_{\mathrm{t}}$ Eqn $[4]$

On the basis of Eqn [4], the rate constant can be determined from a semi-log plot of [D] vs. storage time. The slope of the straight line plot equals the opposite of the rate constant.

\section{Temperature dependence of kinetic constant}

The relationship between reaction rate and temperature was quantified by the Arrhenius relationship (LABUZA \& RIBOH, 1982) :

$$
\mathrm{k}=\mathrm{A}_{\mathrm{o}} \exp (-\mathrm{E} / \mathrm{RT}) \quad \text { Eqn [5] }
$$

where $\mathrm{E}$ is the activation energy of the reaction, $\mathrm{R}=1.987 \mathrm{cal} / \mathrm{g}-\mathrm{mol}^{-} \mathrm{k}$ is the gas constant, $\mathrm{T}$ is absolute temperature, and $A_{\circ}$ is a pre exponentialconstant.

\section{RESULTS AND DISCUSSION}

\section{Changes in color}

Samples of Mei syrup were stored at $5^{\circ} \mathrm{C}, 15^{\circ} \mathrm{C}$ and $25^{\circ} \mathrm{C}$ for 6 and 12 months. respectively. The color differences before and after storage were measured, and the results are presented in Table 1. The "L" value is expression of brightness : the higher the "a" value means the deeper the redness, the lower the " $b$ " value means the thinner the yellowness. The date in Table 1 showed that samples stored at higher temperatures resulted in more changes in color. The most evident change occurred in the brightness of color, Where with a

Table 1 Changes in color of Mei syrup at different storage time and temperatures

\begin{tabular}{ccccc}
\hline \multirow{2}{*}{$\begin{array}{c}\text { Time } \\
\text { (month) }\end{array}$} & Color* & \multicolumn{3}{c}{ Storage temperatures } \\
\cline { 3 - 5 } & & $5{ }^{\circ} \mathrm{C}$ & $15^{\circ} \mathrm{C}$ & $25^{\circ} \mathrm{C}$ \\
\hline \multirow{2}{*}{0} & $\mathrm{~L}$ & $21.3 \pm 1.5$ & $21.3 \pm 1.5$ & $21.3 \pm 1.5$ \\
& $\mathrm{a}$ & -0.2 & -0.2 & -0.2 \\
& $\mathrm{~b}$ & $9.3 \pm 0.6$ & $9.3 \pm 0.6$ & $9.3 \pm 0.6$ \\
& $\mathrm{~L}$ & $19.4 \pm 1.4$ & $17.8 \pm 1.4$ & $16.5 \pm 1.2$ \\
6 & $\mathrm{a}$ & 0.9 & 1.8 & 2.5 \\
& $\mathrm{~b}$ & $8.8 \pm 0.8$ & $8.5 \pm 0.8$ & $8.3 \pm 1.0$ \\
& $\mathrm{~L}$ & $17.2 \pm 1.2$ & $15.2 \pm 1.3$ & $13.9 \pm 1.4$ \\
12 & $\mathrm{a}$ & 1.6 & 3.2 & 4.4 \\
& $\mathrm{~b}$ & $8.4 \pm 0.6$ & $8.2 \pm 0.7$ & $8.0 \pm 0.7$ \\
\hline
\end{tabular}

*L-brightness ; a-redness ; b-yellowness.

Results were obtained by average of three reproduced experiments.

Table 2 The contents of major organic acid in Mei syrup at different storage time and temperatures

\begin{tabular}{ccccc}
\hline \multirow{2}{*}{$\begin{array}{c}\text { Time } \\
\text { (month) }\end{array}$} & $\begin{array}{c}\text { Organic } \\
\text { acid }^{*}\end{array}$ & \multicolumn{3}{c}{ Storage temperatures } \\
\cline { 3 - 5 } 0 & $5{ }^{\circ} \mathrm{C}$ & $15^{\circ} \mathrm{C}$ & $25{ }^{\circ} \mathrm{C}$ \\
\hline \multirow{2}{*}{0} & C.A & 1.17 & 1.17 & 1.17 \\
& M.A & 0.05 & 0.05 & 0.05 \\
& O.A & 0.09 & 0.09 & 0.09 \\
6 & C.A & 1.13 & 1.12 & 1.10 \\
& M.A & 0.05 & 0.05 & 0.05 \\
& O.A & 0.09 & 0.09 & 0.09 \\
12 & C.A & 1.09 & 1.06 & 1.06 \\
& M.A & 0.05 & 0.05 & 0.05 \\
& O.A & 0.08 & 0.08 & 0.08 \\
\hline
\end{tabular}

*C. A. , M. A. , and O. A. represented citric acid, L-mailic acid, and oxalic acid, respectively. Results were obtained by the average of three reproduced experiment 
higher storage temperature, a darker color was observed. Higher storage temperature resulted in increased browning. The results were in agreement with those of WANG and FANG (1988).

\section{Changes in $\mathrm{pH}$ and acidity}

The $\mathrm{pH}$ values of Mei syrup remained unchanged at 2.44. The results of titratable acidity varied in the range of $1.21 \sim 1.33$. The changes in organic acid content during storage are presented in Table 2. The predominant organic acid was citric acid followed by small amounts of oxalic acid and malic acid. CHOU \& FANG (1993) and KAKIUCHI et al. (1985) studied the organic acids in Mei juice of different origin, species and years, and they reported some differences among them. The initial content of organic acid of Dah-Ching cultivar measured in this study was similar to that of $\mathrm{CHOU}$ and FANG (1993) The organic acids, namely citric acid, oxalic acid and malic acid, all had little change during storage. The total free amino acids in Mei syrup during storage varied in the range of $218 \sim 230 \mu \mathrm{M} / 100 \mathrm{~g}$. It indicated that Mei syrup has high acidity and a stable free amino acid content.

\section{Changes in sugars contents}

Changes in sugar contents in Mei syrup during storage are presented in Table 3. The fresh Mei fruit juice contained $0.65 \%$ of glucose and $0.7 \%$ fructose. Sucrose was added to sweeten the juice during preparation of the Mei syrup. The sucrose was disintegrated into glucose and fructose during storage, the phenomenon of the result matches the result gotten from KATO et al. (1963) and KATO \& SAKURAI (1964a). The Mei syrup was blanched during preparation, so the enzyme, including polyphenol oxidase ( $\mathrm{PPO}$ ), were inactivated. Browning occurred in the syrup after heating, therefore it should be a non-enzymatic reaction. The Maillard reaction hardly occurs at a low $\mathrm{pH}$ condition (CHEN et al. , 1994), since the $\mathrm{pH}$ of Mei syrup is around 2.4 and the Maillard reaction dose not seem to be the prime cause responsible for browning in the syrup, thus the caramelization should be an important role factor which was related to the browning of Mei syrup. Figure 2 shows the decrease of the total sugars vs. storage

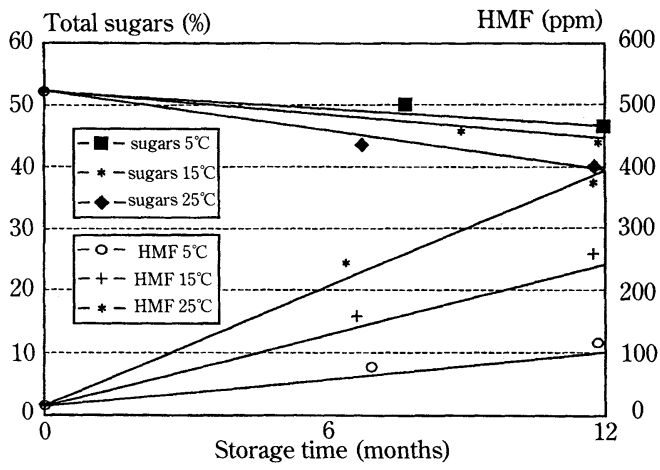

Fig. 2 Relationship between changes in sugars content and the formation of HMF

Table 3 The contents of sucrose, glucose and fructose in Mei syrup at different storage time and temperatures

\begin{tabular}{ccccc}
\hline \multirow{2}{*}{$\begin{array}{c}\text { Time } \\
\text { (month })\end{array}$} & $\begin{array}{c}\text { Sugar } \\
(\%)\end{array}$ & \multicolumn{3}{c}{ Storage temperatures } \\
\cline { 3 - 5 } & Sucrose & $27.8 \pm 1.4$ & $27.8 \pm 1.4$ & $27.8 \pm 1.4$ \\
& Glucose & $12.3 \pm 0.9$ & $12.3 \pm 0.9$ & $12.3 \pm 0.9$ \\
0 & Fructose & $12.1 \pm 0.6$ & $12.1 \pm 0.6$ & $12.1 \pm 0.6$ \\
& Total sugars & 52.2 & 52.2 & 52.2 \\
& Sucrose & $8.2 \pm 0.5$ & $7.8 \pm 0.6$ & $6.1 \pm 0.5$ \\
& Glucose & $22.3 \pm 1.2$ & $21.3 \pm 1.3$ & $20.5 \pm 1.4$ \\
6 & Fructose & $20.9 \pm 1.4$ & $19.6 \pm 1.3$ & $18.6 \pm 1.7$ \\
& Total sugars & 51.4 & 48.7 & 45.5 \\
& Sucrose & 0 & 0 & 0 \\
\multirow{4}{*}{12} & Glucose & $23.1 \pm 1.8$ & $22.3 \pm 1.4$ & $21.3 \pm 1.6$ \\
& Fructose & $22.3 \pm 1.4$ & $21.1 \pm 1.3$ & $19.7 \pm 1.6$ \\
& Total sugars & 45.4 & 43.4 & 41.0 \\
\hline
\end{tabular}

Results were obtained by average of three reproduced experiments.

Table 4 The contents of 5-hydroxymethyl furfural in Mei syrup at different storage time and temperatures

\begin{tabular}{cccc}
\hline \multirow{2}{*}{$\begin{array}{c}\text { Time } \\
\text { (month) }\end{array}$} & \multicolumn{3}{c}{ 5-hydroxymethyl furfural $(\mathrm{ppm})$} \\
\cline { 2 - 4 } & \multicolumn{3}{c}{ Storage temperatures } \\
\cline { 2 - 4 } & $5^{\circ} \mathrm{C}$ & $15^{\circ} \mathrm{C}$ & $25^{\circ} \mathrm{C}$ \\
\hline 0 & $8.5 \pm 0.6$ & $8.5 \pm 0.6$ & $8.5 \pm 0.6$ \\
6 & $52.4 \pm 3.2$ & $132.8 \pm 6.8$ & $215.3 \pm 10.8$ \\
12 & $97.8 \pm 7.5$ & $228.7 \pm 12.1$ & $375.2 \pm 20.7$ \\
\hline
\end{tabular}

Results were obtained by average of three reproduced experiments. 
Table 5 The contents of major phenolic compounds in Mei syrup at different storage time and temperatures

\begin{tabular}{|c|c|c|c|c|}
\hline \multirow{2}{*}{$\begin{array}{c}\text { Time } \\
\text { (month) }\end{array}$} & \multirow{2}{*}{$\begin{array}{c}\text { Phenolic } \\
\text { compounds }(\mathrm{ppm})\end{array}$} & \multicolumn{3}{|c|}{ Storage temperatures } \\
\hline & & $5^{\circ} \mathrm{C}$ & $15^{\circ} \mathrm{C}$ & $25^{\circ} \mathrm{C}$ \\
\hline 0 & $\begin{array}{l}\text { Chlorog } \\
(+) \mathrm{c}\end{array}$ & $\begin{array}{l}40.3 \pm 3.1 \\
26.0 \pm 1.9\end{array}$ & & \\
\hline 6 & $\begin{array}{l}\text { Chlorogenic acid } \\
(+) \text { catechin }\end{array}$ & $\begin{array}{l}28.5 \pm 2.0 \\
15.4 \pm 1.0\end{array}$ & $\begin{array}{l}17.3 \pm 1.5 \\
11.2 \pm 0.9\end{array}$ & $\begin{array}{c}10.6 \pm 1.3 \\
4.2 \pm 0.6\end{array}$ \\
\hline 12 & $\begin{array}{l}\text { Chlorogenic acid } \\
(+) \text { catechin }\end{array}$ & $\begin{array}{c}15.6 \pm 1.2 \\
7.1 \pm 0.5\end{array}$ & $\begin{array}{l}8.7 \pm 0.7 \\
4.8 \pm 0.3\end{array}$ & $\begin{array}{l}3.1 \pm 0.3 \\
1.2 \pm 0.1\end{array}$ \\
\hline
\end{tabular}

Results were obtained by average of three reproduced experiments.

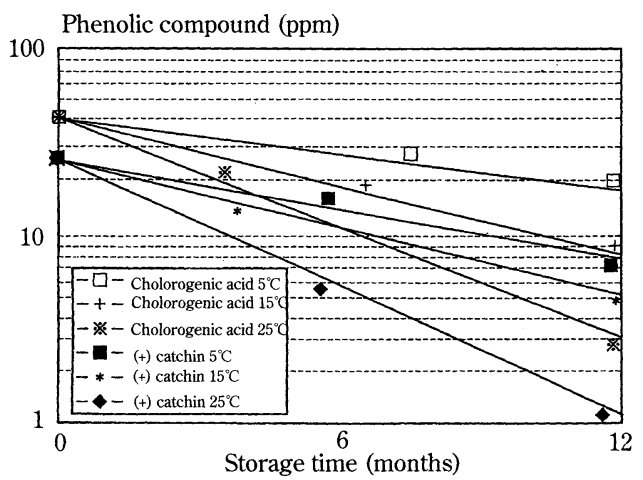

Fig. 3 Changes in phenolic compounds at different time and temperatures

Table 6 Rate constants for changes in sugar, 5hydroxymethyl frufural and phenolic compounds

\begin{tabular}{cccccccc}
\hline \multirow{2}{*}{$\begin{array}{c}\text { Temperature } \\
\left({ }^{\circ} \mathrm{C}\right)\end{array}$} & \multicolumn{3}{c}{ Sugar } & \multicolumn{4}{c}{ HMF } \\
\cline { 2 - 8 } & $\mathrm{c}$ & $\mathrm{k}$ & $\mathrm{r}^{2}$ & $\mathrm{c}$ & $\mathrm{k}$ & $\mathrm{r}^{2}$ \\
$(1 / \mathrm{Mo})$ & & & $(1 / \mathrm{Mo})$ & \\
\hline 5 & 52.2 & 0.567 & 0.837 & 8.5 & 7.44 & 0.99 \\
15 & 52.2 & 0.733 & 0.986 & 8.5 & 18.3 & 0.994 \\
25 & 52.2 & 0.933 & 0.987 & 8.5 & 30.5 & 0.995 \\
\hline \multirow{3}{*}{$\begin{array}{c}\text { Temperature } \\
\left({ }^{\circ} \mathrm{C}\right)\end{array}$} & Chlorogenic & acid & & $(+)$ & Catechin \\
\hline & log & $\mathrm{k}$ & $\mathrm{r}^{2}$ & log & $\mathrm{k}$ & $\mathrm{r}^{2}$ \\
\hline 5 & {$[\mathrm{D}]$.} & $(1 / \mathrm{Mo})$ & & {$[\mathrm{D}]$.} & $(1 / \mathrm{Mo})$ & \\
\hline 15 & 1.605 & 0.079 & 0.976 & 1.415 & 0.108 & 0.987 \\
25 & 1.605 & 0.128 & 0.996 & 1.415 & 0.141 & 0.999 \\
& 1.605 & 0.214 & 0.999 & 1.415 & 0.256 & 0.988 \\
\hline
\end{tabular}

time on a liner plot in accordance with Eqn[2]. The higher the temperature, the faster the rate of degradation was observed.

\section{Changes in 5-hydroxymethyl furfural (HMF) content}

5-hydroxymethyl furfural (HMF) is considered to be an intermediate of caramelization (KATO et al. , 1963; KATO \& SAKURAI 1964a), if detected, caramelization did occur. The HMF can be used as an indicator of caramelization during storage of Mei syrup. The results are presented in Table 4. The relationship between the decrease of total sugars and the increase of intermediate HMF in accordance with the browning progression in the Mei syrup is shown in figure 2. From Table 4. and Figure 2, it is concluded that as the storage time and temperature increase, the more HMF can be formed with a greater degree of browning. Therefore, it is obvious and proper to show that HMF can be regarded as a kind of index for Mei syrup browning.

\section{Changes in phenolic compounds}

The phenolic compounds were analyzed by HPLC, chlorogenic acid and (+) catechin were the basic phenolic compounds in Mei syrup. HUANG (1986) found traces of caffeic acid, ferulic acid and cinnamic acid in the pulp of Mei syrup. However, no measurable quantity was found in our study, so it might be due to the difference in fruit species. The results of phenolic compounds are presented in Table 5. The decreases in phenolic compounds vs. storage time are shown on a semi-log plot in Figure 3. The higher the storage temperature, the faster the decrease of the phenolic compounds was observed. The more oxidation of phenolic compounds there is, the less remains of these compound in Mei syrup, thus, the amount of phenolic compounds in Mei syrup during storage can also be taken as an indication for browning. Table 5 and Figure 3 show that the amount of phenolic compounds is decreasing as the storage time and storage temperature is increasing; which implies that the browning can be caused owing to bave more oxidation of the phenolic compounds. It was indicated that the browning reaction of the sweetened Mei syrup may be due to the caramelization of sugars and the oxidation of the chlorogenic acid and $(+)$ catechin.

\section{Kinetic constants and activation energy}

Eqns [2] and [4] were applied to analyze the rate of changes in sugars, 5-hydroxymethyl 
Table 7 Activation energies and reaction constants for changes in sugars, 5-hydroxymethyl furfural and phenolic compounds

\begin{tabular}{ccccc}
\hline Components & $\begin{array}{c}\text { Temperature } \\
\text { range } \\
\left({ }^{\circ} \mathrm{C}\right)\end{array}$ & $\begin{array}{c}\text { Reaction } \\
\text { constant, } \\
\text { ln A. }\end{array}$ & $\begin{array}{c}\text { Activation } \\
\text { energy } \\
(\mathrm{kcal} / \mathrm{g}-\mathrm{mol})\end{array}$ & $\mathrm{r}^{2}$ \\
\hline Sugars & $5 \sim 25$ & 6.86 & 4.10 & 0.998 \\
5-hydroxymethyl furfural & $5 \sim 25$ & 23.1 & 11.7 & 0.981 \\
Chlorogenic acid & $5 \sim 25$ & 12.3 & 8.19 & 0.998 \\
$(+)$ catechin & $5 \sim 25$ & 10.5 & 7.07 & 0.943 \\
\hline
\end{tabular}

furfural, and phenolic compounds, respectively, as a function of time. Eqn [2] is better fitted for total sugar decreases and 5-hydroxymethyl frufural increases than Eqn [4]. On the contrary, Eqn [4] is better fitted for phenolic compounds increase than Eqn [2]. The rate constants of the suitable equations for each component are presented in Table 6. Assuming an Arrhenius relationship between rate constant and temperature, thus, the activation energies and reaction velocity constants were calculated from Eqn [5]. The results are summarized in Table 7.

\section{CONCLUSIONS}

Sweetened mei syrup stored at $5{ }^{\circ} \mathrm{C}, 15^{\circ} \mathrm{C}$ and $25^{\circ} \mathrm{C}$ for six months and twelve months, respectively, suffered various degrees of browning reaction. The $\mathrm{pH}$ of the syrup remained constant, and the titratable acidity, contents of organic acid and total free amino acids were decreased only slightly; while the sucrose in the Mei syrup was completely inverted into fructose and glucose in twelve months storage. The total sugars decreased as the syrup browning progressed. The contents of phnolic compounds, chlorogenic acid and $(+)$ catechin decreased during storage. The rate of total sugar degradation and 5-hydroxymethyl furfrual increases could be characterized in terms of zero order kinetics while decreases in phenolic compounds were better fitted by a first-order kinetics. The experimental rate constants can be used advantageous to analyze the browning speed of Mei syrup during storage. .

\section{REFERENCES}

1) Bergmeyer, H. U. and Bernt, E. (1974).
Enzymatic determination of sucrose, D-glucose and D-fructose In "Methods of Enzymatic Analysis” (BERGMEYer, H. U. ed) 2nd ed., vol. 3. p. $1176 \sim 1179$. Verlag Chemie Weinheim, Academic Press, Inc., New York and London. 2) Chinese National Standard (CNS) . (1980). Fruit and Vegetable Drinks. Original No. 2377. Central Standard Bureau of Ministry of Economic Affairs, Executive Yuan, R. O. C.

3) Chang, C. M. and WU, J. S. B. (1985). Debittering of Japanese apricot (Prunus mume) juice with kernel extract. J. Chinese Agric. Chem. Soc. $23(3,4): 282 \sim 287$.

$4)$ ChOU, C. H. and FAnG, T. T. ( 1993 ). Investigation of the fruit characteristics of Japanese apricot or mei (Prunus mume Seib. et Zucc. ) in Taiwan. Memoirs of the College of Agriculture National Taiwan University 33 (1) : 31 44.

5) Chen, M. L. , LeE, C. Y. and Wu, J. S. B. (1994). An evaluation of some possible mechanisms for nonenzymatic browning in guava nectar during storage. Food Sci. 21 (4) : 293 303.

6) FAng. T. T. and WANG, D. Y. (1988). Preparation and processing if Japanese apricot nectar. Food Ind. 20 (3) : 36 43.

7) Huang, T. C. (1986) . Pigment composition and color changes during processing of mei (plum) . In "Role" of Chemistry in the Quality of Processed Food". Food and Nutrition Press, Inc. Westport pp. 108 117.

8) Jose, R. R. M. and LuH, B. S. (1973) . Phenolic compounds in frozen avocados. J. Sci. Agric. 24 : 219 223.

9) KaKiUchi, N, Ishalawa, K. , MoRiguchi, S., 
Kyotani H. and YoshidA, M. (1985) .Studies on composition and processing suitability of mume fruit. I. Changes in organic and free amino acid compositions in relation to variety and harvest maturity. J. Japanese Soc. Food Sci. Tech. 32 (9) : 669 676.

10) K'ANG, Y. D. (1995) . Horticultural crop, Fruit section II. 2. Mei. Taiwan agriculture encyclopedia (crop Edition-3) . pp. 789 793.

11) Kato, H. , Ichinata, H. and Fujimaki, M. (1963) . Studies on browning mechanisms of fruit juice products.Part I. Changes in chemical composition which accompany browning of commercial concentrated lemon juice during storage. J. of Japanese of Agricultural Chemistry 37 (4) : $220 \sim 225$.

12) Kato, H. and SaKURAI, Y. (1964a). Studies on browning mechanisms of fruit juice products. Part II. Effect of various compounds on the browning of socalled concentrated lemon beverage. Nippon Shokuhi Kogyo Gakkaishi, 11 (8) : 313 316.

13) Kato, H. and SaKURAI, Y. (1964b) . Studies on browning mechanisms of fruit juice products. Part III. Mechanisms of browning in citric acidsucrose system. J. of Japanese of Agricultural Chemistry, 38 (11): 536 541.

14) LabuZA, T. D. and RiBOH, D. (1982) . Theory and application of Arrhenius kinetics to the prediction of nutrient losses in foods. Food Tech. 36 (10) : 55 74.

15) ORIMO, T. (1975) . Soft drink syrups. Japanese patent 5026 629, 5026630 .

16) WANG, D. Y. and FANG, T. T. (1988) . Studies on the preparation of Japanese apricot fruit juice II. Debitterization and prevention of browning reaction in nectar processing. Memoirs of the Collage of Agriculture National Taiwan University 28 (1) : 39 45.

17 ) Wilson, C. W. , Shaw, P. E. , and
CAnPhell, C. W. (1982). Determination of organic acid and sugars in guava (Psidium quajava L. ) cultivates by high performance liquid chromatography. J. Sci Food Agric. 33 : 777 $\sim 780$.

18) Wulf, L. W. and NAgel, C. W. (1976), Analysis of phenolic acids and flavonoids by high pressure liquid chromatography. J.Chromatography $116: 217 \sim 275$.

\section{梅シロップ貯蔵中の褐変要因と光の速度解析}

\author{
呉明昌* 楊 廷珍** CHEN Chin Shu*** \\ * 國立㞔東科技大學食品技術系 \\ (台灣犚東縣内埔鄉學府路一號) \\ **仕全實業有限公司 \\ (台灣台中市英才路605號 4 樓) \\ *** Institute of Food and Agricultural \\ Sciences, University of Florida \\ (IFAS, 700 Experiment Station Road, \\ Lake Alfred, FL33850. USA)
}

梅シロップを $5{ }^{\circ} \mathrm{C}, 15^{\circ} \mathrm{C}$ 及び $25^{\circ} \mathrm{C}$ の温度別に， 6 ケ 月と 12 ケ月の時間別に貯蔵した後, 品質が劣化する結 果を得た。シロップのPHは変わらないが, 滴定酸や有 機酸及び遊離アミノ酸の総量はやや減少し, そして, 12 ケ月貯蔵した場合, シロップ内のスクロースは全部フル クトースと,グルコースに変わった。総スクロース量は シロップの褐色化につれて減少し, フェノール物質, ク ロロゲン酸とカテキン (CATECHIN) の量は, 貯蔵 と共に減少していった。総スクロースの変化率と 5 -七 ドロキシメチール フルフラール（HMF）はキャラメ ルの中間物質で, 貯蔵したシロップの中で見つけられて いる。貯蔵期間中に於ける糖分及びフェノール化合物の 動力学的係数は減少した。砂糖を添加した梅シロップの 褐変は, フェノール化合物の酸化と糖分のキャラメル化 の，相互作用にあったことが認められる。

(平成 9 年 8 月 27 日受理) 